\title{
Covid-19 Dalam Kolom Opini Koran Kompas: Sebuah Analisis Argumentasi
}

\author{
Covid-19 In the Opinion Column of Kompas Newspaper: An Argument Analysis \\ Wulan Pusposari*1, Makyun Subuki ${ }^{2}$, Nuryani ${ }^{3}$ \\ 1,2,3 Program Studi Bahasa dan Sastra Indonesia, Fakultas Ilmu Tarbiyah dan Keguruan, Universitas \\ Islam Negeri Syarif Hidayatullah Jakarta, Indonesia \\ e-mail: *I'wulanpusposari97@gmail.com, ${ }^{2}$ makyun.subuki@uinjkt.ac.id, ${ }^{3}$ nuryani@uinjkt.ac.id
}

\begin{abstract}
ABSTRAK
Percepatan kemajuan teknologi menjadikan koran atau surat kabar harus besikap adaptif dengan tampil dalam versi daring dan luring. Kolom opini dalam koran adalah medium bagi penulis untuk menyampaikan gagasan besar pemikirannya. Akan ada banyak argumentasi di luar sana, terutama di masa wabah Covid19, karena hampir seluruh masyarakat dunia terfokus pada hal ini. Penelitian ini bertujuan untuk mendeskripsikan unsur-unsur argumentasi pada kumpulan tulisan yang terdapat kata "Covid-19" di setiap judul kolom Opini di koran Kompas versi daring (13 Juli 2020 - 13 Agustus 2020). Secara garis besar metode penelitian ini disebut deskriptif kualitatif. Pengumpulan data bertumpu dengan pengarsipan secara dokumentasi dan penelusuran daring hingga pengkategorian judul artikel. Teknik analisis data menggunakan teknik analysis content. Hasil penelitian yaitu terpilih 10 artikel yang terdapat kata "Covid19" disetiap judul kolom Opini di koran Kompas versi daring. Adapun kelengkapan unsur-unsur argumentasi kesepuluh tulisan tersebut yaitu kesepuluh artikel telah memenuhi elemen utama unsur-unsur argumentasi yakni claim, data, dan warrant. Namun kesepuluh artikel tidak mendekati kesempurnaan unsur dengan memenuhi elemen pelengkap unsur-unsur argumentasi yaitu backing, qualifer, dan rebuttal.
\end{abstract}

Kata kunci: Argumentasi, Covid-19, Surat Kabar, Kolom Opini

\begin{abstract}
The acceleration of technological advances makes newspapers or newspapers have to be adaptive by appearing in online and offline versions. The opinion column in the newspaper is a medium for the writer to convey his big ideas. There will be a lot of arguments out there, especially during the Covid-19 outbreak, because almost the entire world community is focused on this. This study aims to describe the elements of argumentation in a collection of writings that contain the word "Covid-19" in each Opinion column title in the online version of the Kompas newspaper (13 July 2020 - 13 August 2020). Broadly speaking, this research method is called qualitative descriptive. Data collection relies on documenting and searching online to categorizing article titles. Data analysis techniques using content analysis techniques. The results of the study were 10 articles that contained the word "Covid-19" in each of the Opinion column headings in the online version of the Kompas newspaper. As for the completeness of the argumentation elements of the ten articles, namely the ten articles have fulfilled the main elements of the argumentation elements, namely claims, data, and warrant. However, the ten articles do not approach the perfection of the elements by fulfilling the complementary elements of the argumentation elements, namely backing, qualifer, and rebuttal.
\end{abstract}

Keywords: Argument, Covid-19, Newspaper, Opinion Column.

\section{PENDAHULUAN}

Salah satu kemampuan manusia dalam berbahasa adalah mengkonversi hasil pikirannya ke dalam bentuk gagasan yang dilisankan maupun dituliskan. Gagasan sebagai bentuk konsep abstrak dalam pikiran yang kemudian berusaha untuk dirangkai hingga diterjemahkan dalam bentuk pendapat. Pendapat atau yang sering disebut opini, gagasan, dan argumentasi ini yang merupakan sebuah pandangan atau buah pikiran seseorang terhadap suatu isu/topik dan mengandung unsur-unsur argumentasi di dalamnya. Pada prinsipnya seseorang mengemukakan pendapatnya untuk menjelaskan pendapat yang dimilikinya agar diyakini pula oleh pembaca atau pendengarnya. Hal yang tidak boleh lupa bahwa argumen yang dikemukakan tetap harus logis, menjauhkan emosi atau unsur subjektif, dan tidak menggunakan bahasa yang multitafsir. Kemudian manusia juga tanpa disadari, dirinya terkadang sedang mengutarakan argumentasi, 
Jurnal SEMANTIKA, Volume 2, No. 02, Februari 2021, pp. 16-27

karena dari berbagai jenis komunikasi seperti bercerita, debat, berdiskusi, bahkan bertengkar, secara alamiah seseorang akan mengungkapkan pendapatnya kepada mitra tuturnya. Argumen adalah proses alami komunikasi manusia[1]. Hal ini sejalan dengan pendapat [2] argumentasi adalah produk dan proses. Terkadang fokus kita adalah pada pesan, produk dari argumentasi. Pesan bersifat eksplisit dan implisit. Mereka dapat dilemparkan ke dalam bahasa, dianalisis, dan dinilai.

Unsur-unsur argumentasi yaitu komponen-komponen argumen yang secara lengkap mencakup (1) claim atau pernyataan posisi (C), (2) data atau fakta (D), (3) warrant atau jaminan (W), (4) backing atau pendukung (B), (5) modal qualifier atau keterangan modalitas (Q), dan (6) rebuttal atau pengecualian atau bantahan (R)[3]. Hal ini yang menjadikan definisi argumentasi dimana argumen yang sebenarnya hanyalah sepotong wacana atau tulisan di mana seseorang mencoba meyakinkan orang lain (atau dirinya sendiri) tentang kebenaran klaim dengan mengutip alasan atas namanya[4].

Di era digital seperti saat ini, seseorang akan jauh lebih mudah mengutarakan pendapat atau argumentasinya. Kemajuan peradaban oleh mesin-mesin pencetak bahkan kekuatan sistem perangkat lainnya seperti internet yang mulai membangun dunia baru bagi manusia yakni dunia digital. Memunculkan media baru seseorang untuk bisa saling berkomunikasi dan beropini, beberapa media tersebut yakni email, facebook, twitter, whatsapp, website, dan lain sebagainya. Namun demikian, ada satu media cetak yang tetap eksis keberadaannya hingga saat ini yaitu koran. Walaupun beberapa tampilan koran yang ada di Indonesia mulai menyesuaikan bentuknya dengan era digital saat ini. Hal ini karena media cetak seperti surat kabar harus memiliki layanan berita daring melalui website karena meningkatnya penggunaan internet di masyarakat. Asosiasi Penyelenggara Jasa Internet Indonesia (APJII) melakukan survei mengenai Penetrasi \& Perilaku Pengguna Internet Indonesia tahun 2017. Hasil survei itu menunjukkan penetrasi pengguna internet di Indonesia meningkat menjadi 143,26 juta jiwa atau 54,68 persen dari 262 juta jiwa penduduk negeri ini. Berdasarkan survei yang dilakukan APJII pada tahun 2016, jumlah pengguna internet Indonesia mencapai 132,7 juta jiwa[5].

Koran sebagai lembaran-lembaran kertas yang bertuliskan berita, opini, iklan, dan lain sebagainya yang terbagi dalam beberapa kolom, dan di produksi secara periodik. Koran juga merupakan salah satu media untuk menyalurkan gagasan yang terbendung dalam pikiran manusia melalui karya tulis. Kolom opini dalam koran Kompas termasuk rubrik yang paling populer, karena ada banyak penulis profesional yang juga ikut mengajukan tulisannya agar dapat lolos dan dimuat dalam koran tersebut. Jadi pada prinsipnya peran kolom Opini dalam koran Kompas berfungsi untuk menyebarkan ilmu dan informasi kepada khalayak umum yang siap dipertanggungjawabkan nantinya. Adapun perkembangan surat kabar digital yang menggunakan internet dapat diakses dengan mudah asalkan terdapat koneksi, sehingga dapat menjangkau lebih banyak pembaca lebih cepat[6].

Akhir tahun 2019 adalah awal kemunculan virus Covid-19, hingga menjadi wabah dunia. Dunia dikejutkan dengan mewabahnya pneumonia baru yang kemudian menyebar dengan cepat. Covid-19 adalah harus diwaspadai karena memiliki tingkat moralitas yang tidak dapat diabaikan, dan belum adanya terapi definiti[7]. Penelitian ini akan mengangkat isu-isu yang menarik di dalam koran. Bahwa dari sekian banyak informasi yang dihadirkan dalam kolom-kolom koran, ada hal yang bisa diteliti, yakni terutama kolom opini. Terlebih di masa wabah Covid-19 ini, sangat penting untuk membekali diri dengan wawasan yang luas, agar semakin bijak dalam menyikapi fenomena yang terjadi. Melalui kolom Opini koran Kompas yang berisi penulis profesional menjadi pijakan untuk melihat gagasan serta argumentasi mengenai Covid-19 yang mereka lontarkan pada khalayak luas.

Di masa wabah Covid-19 berbagai penelitian yang berkenaan dengan hal tersebut menjadi sangat menarik, selain karena menjadi isu global, juga sebagai bagian dari cara menanggulangi wabah tersebut. Melalui berbagai hasil penelitian yang dilakukan oleh para peneliti dari berbagai bidang, hal ini dapat dijadikan bekal dalam merespons sekaligus adaptif di tengah situasi pandemi ini. Beberapa di antara bidang tersebut yakni pembelajaran atau dunia pendidikan, sebagaimana pendidikan merupakan salah satu aspek kehidupan yang terdampak 
pandemi Covid-19 yakni munculnya tuntutan proses pembelajaran jarak jauh berbasis teknologi daring[8]. Bahkan dunia kebahasaan pun juga turut terdampak, terlihat pada gerakan memakai masker melalui banner atau lainnya. Dengan kenyataan banyak lambang atau tanda yang sukar diketahui oleh masyarakat biasa[9]. Hal ini yang menjadikan penelitian mengenai Covid-19 dari berbagai bidang perlu dilakukan

\section{METODOLOGI PENELITIAN}

Saat ini peradaban manusia sedang mengalami krisis kesehatan, dikarenakan virus baru bernama Covid-19 yang meluas pertumbuhannya hingga menjadi wabah dunia. Hal ini menjadikan Covid-19 sebagai bahan perbincangan di seluruh negara. Dengan demikian menjadi menarik untuk tetap melibatkan isu ini ke dalam penelitian. Pilihan yang diambil dalam penelitian ini adalah koran Kompas (daring) yang berfokus pada kolom Opini. Data diperoleh dengan metode dokumentasi dan penelusuran daring selama satu bulan (13 Juli - 13 Agustus 2020), ditemukan 85 kolom Opini. Kemudian difokuskan penelitian pada kolom Opini dengan judul yang terdapat kata "Covid-19", ditemukan sebanyak 10 kolom.

\section{HASIL DAN PEMBAHASAN}

Peneliti mengumpulkan data dengan menggunakan metode dokumentasi dan metode penelusuran daring. Surat kabar Kompas dalam versi daring dipilih dalam penelitian ini yang berfokus pada kolom Opini. Peneliti mendokumentasikan data melalui penelusuran daring sehingga memperoleh data sebanyak 85 artikel seperti Tabel 1.

Table 1. Penelusuran daring data

\begin{tabular}{|c|c|c|c|}
\hline No & Kata Kunci & Tanggal & Judul \\
\hline 1 & \multirow{5}{*}{ Pandemi } & 17-Jul-20 & Evaluasi Komunikasi Pandemi \\
\hline 2 & & 24-Jul-20 & Cetak Uang Saat Pandemi \\
\hline 3 & & 30-Jul-20 & Idul Kurban di Tengah Pandemi \\
\hline 4 & & 04-Agust-20 & Kampanye di Musim Pandemi \\
\hline 5 & & 08-Agust-20 & Manajemen Publik Pandemi \\
\hline 1 & \multirow{10}{*}{ Covid-19 } & 13-Jul-20 & Covid-19, "Great Reset", SDGs \\
\hline 2 & & 13-Jul-20 & Mengapa Masyarakat Anggap Enteng Covid-19 \\
\hline 3 & & 13-Jul-20 & Covid-19, Perlu Pemantauan Berkelanjutan di Hilir \\
\hline 4 & & 17-Jul-20 & $\begin{array}{l}\text { Apa Setelah Demam Babi Afrika, Covid-19, dan Flu } \\
\text { Babi? }\end{array}$ \\
\hline 5 & & 17-Jul-20 & Covid-19 dan Kesehatan Masyarakat \\
\hline 6 & & 20-Jul-20 & Covid-19 dan Pembangunan \\
\hline 7 & & 03-Agust-20 & Otopsi Jenazah Korban Covid-19 \\
\hline 8 & & 04-Agust-20 & Bebas dari Cacar dan Covid-19 \\
\hline 9 & & 05 -Agust-20 & Covid-19 dan Aspek Historikal Struktural BUMN \\
\hline 10 & & 12-Agust-20 & Meluruskan Infodemi Covid-19 \\
\hline 1 & \multirow{3}{*}{$\begin{array}{l}\text { Pendapatan } \\
\text { Negara }\end{array}$} & 14-Jul-20 & $\begin{array}{l}\text { Negara Berpendapatan Menengah Atas, Mengapa } \\
\text { Baru Sekarang }\end{array}$ \\
\hline 2 & & 16-Jul-20 & $\begin{array}{l}\text { Setelah Indonesia Naik ke Kelompok Pendapatan } \\
\text { Menengah Atas }\end{array}$ \\
\hline 3 & & 16-Jul-20 & $\begin{array}{l}\text { Peluang dan Tantangan Menjadi Negara } \\
\text { Berpendapatan Menengah Atas }\end{array}$ \\
\hline 1 & \multirow{4}{*}{$\begin{array}{l}\text { Petani dan } \\
\text { Pertanian }\end{array}$} & 25-Jul-20 & $\begin{array}{l}\text { "Food Estate", Pertanian Kecil dan Ketahanan } \\
\text { Nasional }\end{array}$ \\
\hline 2 & & 03-Agust-20 & Memotret Sektor Pertanian Secara Utuh \\
\hline 3 & & 05-Agust-20 & RUU Cipta Kerja Versus Petani \\
\hline 4 & & 12-Agust-20 & Pertanian tanpa Petani \\
\hline 1 & \multirow{3}{*}{ Normal Baru } & 16-Jul-20 & Peran Keluarga Era Normal Baru \\
\hline 2 & & 23-Jul-20 & UMKM, Normal Baru, dan Transportasi \\
\hline 3 & & 06-Agust-20 & Menghijaukan Kenormalan Baru \\
\hline 1 & \multirow{3}{*}{ Anak } & 24-Jul-20 & Urgensi Pemda Lindungi Anak \\
\hline 2 & & 05-Agust-20 & Hentikan Kekerasan pada Anak \\
\hline 3 & & 11-Agust-20 & Memperluas Pemahaman Viktimisasi Anak \\
\hline
\end{tabular}


Jurnal SEMANTIKA, Volume 2, No. 02, Februari 2021, pp. 16-27

\begin{tabular}{|c|c|c|c|}
\hline 1 & \multirow{5}{*}{ Pangan } & 24-Jul-20 & Basis Pertahanan Berdaulat Pangan \\
\hline 2 & & 25-Jul-20 & Cadangan Strategis Pangan \\
\hline 3 & & 28-Jul-20 & Lumbung Pangan Berkelanjutan \\
\hline 4 & & 03-Agust-20 & Lumbung Pangan Nasional \\
\hline 5 & & 06-Agust-20 & Mitigasi Lumbung Pangan Baru \\
\hline 1 & \multirow[b]{2}{*}{$\begin{array}{l}\text { Perguruan } \\
\text { Tinggi }\end{array}$} & 29-Jul-20 & Konvergensi Tridarma Perguruan Tinggi \\
\hline 2 & & 23-Jul-20 & $\begin{array}{l}\text { Tantangan Perguruan Tinggi: untuk Apa Bayar Mahal } \\
\text { jika Hanya Daring? }\end{array}$ \\
\hline 1 & \multirow{3}{*}{ Kemiskinan } & 20-Jul-20 & Data Kemiskinan, Kemiskinan Data \\
\hline 2 & & 21-Jul-20 & Bantuan Efektif Menahan Kemiskinan \\
\hline 3 & & 13-Agust-20 & Daya Beli Penduduk Miskin \\
\hline
\end{tabular}

Tabel 1 dikelompokkan berdasarkan kata kunci yang hadir disetiap judul kolom Opini pada surat kabar Kompas. Kemudian peneliti memilih kumpulan tulisan yang terdapat kata kunci "Covid-19" sebanyak 10 artikel. Kumpulan tulisan tersebut terdapat pada Tabel 2

Table 2. Hasil pengumpulan artikel covid-19

\begin{tabular}{cll}
\hline No & \multicolumn{1}{c}{ Judul } & \multicolumn{1}{c}{ Penulis } \\
\hline 1 & Covid-19, "Great Reset", SDGs & Suharso Monoarfa \\
\hline 2 & Mengapa Masyarakat Anggap Enteng Covid-19 & Abdul Malik Gismar \\
\hline 3 & Covid-19, Perlu Pemantauan Berkelanjutan di Hilir & Erman Aminullah \\
\hline 4 & Apa Setelah Demam Babi Afrika, Covid-19, dan Flu Babi? & Soeharsono \\
\hline 5 & Covid-19 dan Kesehatan Masyarakat & Dono Widiatmoko \\
\hline 6 & Covid-19 dan Pembangunan & Emil Salim \\
\hline 7 & Otopsi Jenazah Korban Covid-19 & Djoko Santoso \\
\hline 8 & Bebas dari Cacar dan Covid-19 & FX Wikan Indrarto \\
\hline 9 & Covid-19 dan Aspek Historikal Struktural BUMN & Fachry Ali \\
\hline 10 & Meluruskan Infodemi Covid-19 & Hari Kusnanto \\
\hline
\end{tabular}

Kesepuluh artikel ini yang akan menjadi objek atau bahan penelitian. Di masa wabah Covid19 ini akan menjadi menarik untuk dapat mengetahui gagasan atau argumen ilmiah yang dilontarkan oleh para tokoh di luar sana. Terlebih dalam penelitian ini melalui medium kolom Opini pada surat kabar Kompas versi daring. Kesepuluh tulisan tersebut akan dianalisis terkait unsur-unsur argumentasi yang ada di dalam teks seperti, elemen pokok argumentasi yakni Claim, Data, Warrant, serta elemen pelengkapnya yakni Backing, Modal, dan Rebuttal. Table 3 adalah unsur-unsur argumentasi dari kesepuluh tulisan dalam rubrik Opini di koran Kompas

Table 3. Unsur argumentasi

\begin{tabular}{|c|c|c|c|c|c|c|c|}
\hline \multirow[b]{2}{*}{ No } & \multirow[b]{2}{*}{ Judul Tulisan } & \multicolumn{6}{|c|}{ Unsur-Unsur Argumentasi } \\
\hline & & Claim & Data & Warrant & Backing & $\begin{array}{c}\text { Modal } \\
\text { Qualifiers }\end{array}$ & Rebuttal \\
\hline 1 & Covid-19, "Great Reset", SDGs & $\mathrm{v}$ & $\mathrm{V}$ & $\mathrm{V}$ & $\mathrm{V}$ & $\mathrm{V}$ & - \\
\hline 2 & $\begin{array}{l}\text { Mengapa Masyarakat Anggap Enteng } \\
\text { Covid-19 }\end{array}$ & $\mathrm{v}$ & $\mathrm{v}$ & $\mathrm{v}$ & $\mathrm{v}$ & $\mathrm{v}$ & - \\
\hline 3 & $\begin{array}{l}\text { Covid-19, Perlu Pemantauan } \\
\text { Berkelanjutan di Hilir }\end{array}$ & $\mathrm{v}$ & $\mathrm{v}$ & $\mathrm{v}$ & - & $\mathrm{v}$ & - \\
\hline 4 & $\begin{array}{l}\text { Apa Setelah Demam Babi Afrika, Covid- } \\
\text { 19, dan Flu Babi? }\end{array}$ & $\mathrm{v}$ & $\mathrm{v}$ & $\mathrm{v}$ & - & $\mathrm{V}$ & - \\
\hline 5 & Covid-19 dan Kesehatan Masyarakat & $\mathrm{V}$ & $\mathrm{V}$ & $\mathrm{V}$ & $\mathrm{V}$ & $\mathrm{V}$ & - \\
\hline 6 & Covid-19 dan Pembangunan & $\mathrm{V}$ & $\mathrm{V}$ & $\mathrm{V}$ & $\mathrm{V}$ & $\mathrm{V}$ & - \\
\hline 7 & Otopsi Jenazah Korban Covid-19 & $\mathrm{V}$ & $\mathrm{V}$ & $\mathrm{V}$ & - & $\mathrm{V}$ & - \\
\hline 8 & Bebas dari Cacar dan Covid-19 & $\mathrm{v}$ & $\mathrm{V}$ & $\mathrm{V}$ & $\mathrm{V}$ & $\mathrm{V}$ & - \\
\hline 9 & $\begin{array}{l}\text { Covid-19 dan Aspek Historikal Struktural } \\
\text { BUMN }\end{array}$ & $\mathrm{v}$ & $\mathrm{V}$ & $\mathrm{v}$ & $\mathrm{V}$ & $\mathrm{V}$ & - \\
\hline 10 & Meluruskan Infodemi Covid-19 & $\mathrm{V}$ & $\mathrm{V}$ & $\mathrm{V}$ & $\mathrm{V}$ & $\mathrm{V}$ & - \\
\hline
\end{tabular}

\section{Covid-19, "Great Reset", SDGs}

Unsur pertama yaitu claim, claim dapat diartikan sebagai gagasan pembicaraan. Claim pada artikel ini yaitu "Tahun 2020 akan selamanya dikenang sebagai periode krisis yang hanya bisa disetarakan dengan Depresi Besar 1930-an". Claim tersebut tidak berdiri sendiri. Claim akan kuat kedudukannya apabila terdapat data-data yang berkaitan dengan claim. Adapun data yang 
Jurnal SEMANTIKA, Volume 2, No. 02, Februari 2021, pp. 16-27

mendukung claim yakni: "di masa pandemi kita menyaksikan Bumi yang semakin ringkih karena menopang hampir delapan miliar manusia dan segera berada di "titik kulminasi"”." Titik kulminasi yang dimaksudkan yakni proyeksi yang diperkirakan para ilmuwan bahwa 17 tahun lagi, apabila manusia tetap bersikeras dengan pola kehidupan seperti saat ini, maka di masa depan dunia akan semakin rentan menghadapi berbagai krisis. Data berikutnya yaitu " $d i$ dunia, Great reset akan menjadi tema besar pertemuan prestisius Forum Ekonomi Dunia, Indonesia telah mengarustamakan SDGs dalam dokumen Rencana Pembangunan Jangka Menengah Nasional (RPJMN) 2020-2024.”. Pernyataan ini merupakan data, bahwa Covid-19 telah menyadarkan atau membangunkan ulang diri kita yang harus menjalankan kehidupan dengan cara yang berbeda. Penting untuk kita me-reset ulang apa yang telah kita lakukan sebelumnya, dengan meninggalkan kebiasaan masa lalu yang tak kompatibel dengan masa depan. Selanjutnya adalah warrant. Warrant dalam artikel ini yaitu "Dinamika krisis yang terjadi erat kaitannya dengan kondisi Bumi serta kelajuan pertambahan penduduknya. Dengan demikian penting berbagai negara diseluruh belahan dunia harus hadir dalam mengatur ulang peradaban ini.". Pernyataan tersebut menghubungkan claim dengan data yang ada di artikel ini. Selanjutnya yaitu backing. Di dalam artikel ini backing yaitu: "Sangat beruntung, dunia telah memiliki Tujuan Pembangunan Berkelanjutan (SDGs), bagi semua pemangku kepentingan, baik pemerintah maupun nonpemerintah, di seluruh dunia untuk menjalankan kehidupan berkelanjutan.”. Backing tersebut adalah fakta. SDGs atau istilah yang kerap didengar yakni Sustainable Development Goals. SDGs adalah cara yang juga ditempuh dunia untuk menjaga kestabilan peradaban manusia. Dengan adanya bukti tersebut menjadi jelas bahwa kestabilan kondisi Bumi menjadi perhatian serius dan dapat menjadi faktor atau pemicu krisis jika terjadi ketidakstabilan dalam kondisi Bumi. Serta kehadiran berbagai negara yang juga memiliki Tujuan Pembangunan Berkelanjutan (SDGs) adalah kebenaran yang perlu dikawal agar terwujud dan keberlangsungan Bumi ini tidak hanya untuk generasi hari ini tetapi juga untuk masa yang akan datang. Dengan begitu backing di atas adalah fakta yang mampu mendukung warrant. Unsur selanjutnya yaitu qualifer. Qualifer dalam artikel ini terdapat kata penanda "akan" pada pernyataan di claim. Unsur argumentasi yang terakhir yaitu rebuttal. Kendati demikian dalam artikel ini tidak ditemukan atau tidak memiliki unsur rebuttal terhadap claim.

\section{Mengapa Masyarakat Anggap Enteng Covid-19}

Unsur pertama yaitu claim, Claim pada artikel opini ini yaitu "Persepsi terhadap suatu risiko menentukan perilaku menghadapi risiko itu. Risiko Covid-19 tidak biner atau dikotomis berisiko vs tidak berisiko. Oleh karena itu, secara obyektif risiko penularan Covid-19 juga tak sama untuk semua kegiatan.". Pengarang mengulik hal mendasar dalam membentuk perhatian masyarakat terhadap pandemi Covid-19, khususnya pada masyarakat Indonesia. Karena sumber informasi yang dikonsumsi masyarakat amat luas dan bebas sehingga hal ini dapat memunculkan banyak persepsi bagi setiap pembacanya, dan dapat menyebabkan keterbelahan pemikiran dan kekaburan sikap dalam menghadapi wabah Covid-19 ini. Bagaimana sains di balik risiko Covid-19 ini sangat kompleks, melibatkan pengetahuan mengenai virus itu sendiri, dan lingkungan seperti apa yang dapat menyebarkannya, serta perilaku manusia seperti apa yang memudahkan penyebarannya. Pemahaman mengenai risiko Covid-19 akan membantu persepsi risiko yang akurat untuk setiap kegiatan yang akan dilakukan. Claim tersebut tidak berdiri sendiri. Claim akan kuat kedudukannya apabila terdapat data-data yang berkaitan dengan claim. Adapun data yang mendukung claim yakni "Social Resilience Lab Nanyang Technological University menyimpulkan bahwa Jakarta belum siap untuk normal baru karena sebagian besar warga Jakarta (77 persen) menganggap enteng Covid-19”. Terkait Covid-19, arti normal baru merujuk pada sikap, perilaku, dan tatanan sosio-kultural baru yang muncul sebagai reaksi dan adaptasi terhadap virus ini. Pilihan terkait "keluar rumah" dan "tidak keluar rumah" adalah bukan pilihan, karena biaya ekonomi, sosial, kultural, dan psikologis dari "tinggal di rumah" berkepanjangan sangat nyata. Akan tetapi, melakukan kegiatan sehari-hari dan menganggap enteng risiko Covid-19 adalah sangat berbahaya. Setelah ditemukan data dan claim maka unsur 
Jurnal SEMANTIKA, Volume 2, No. 02, Februari 2021, pp. 16-27

selanjutnya adalah warrant. Warrant dalam artikel ini yaitu "Pengetahuan dan pemahaman penularan Covid-19 harus jadi fokus utama untuk menyiapkan tatanan kehidupan baru.". Pernyataan tersebut menghubungkan claim dengan data yang ada di artikel ini. Unsur selanjutnya yaitu backing. Di dalam artikel ini ditemukan backing yaitu "Sekali lagi yang diperlukan adalah kampanye kesehatan masyarakat yang masif dan intensif. Untuk ini diperlukan kebijakan, program, dan kegiatan yang sinkron dan ketat terintegrasi secara vertikal lintas tingkatan pemerintahan dan secara horizontal lintas lembaga; serta disampaikan dalam bahasa yang dimengerti masyarakat.". Dengan adanya bukti tersebut menggambarkan bahwa negara memang sedang bergerak ke arah sana. Sebagaimana kampanye secara konvensional sebagai usaha indoktrinasi. Bahwa pengetahuan dan penularan Covid-19 harus dipahami secara meluas, sebagai usaha untuk menyiapkan tatanan kehidupan baru. Dengan begitu backing di atas adalah fakta yang mampu mendukung warrant. Unsur selanjutnya yaitu qualifer. Qualifer dalam artikel ini terdapat kata penanda "oleh karena itu" pada pernyataan di claim. Unsur argumentasi yang terakhir yaitu rebuttal. Kendati demikian dalam artikel ini tidak ditemukan atau tidak memiliki unsur rebuttal terhadap claim.

\section{Covid-19, Perlu Pemantauan Berkelanjutan di Hilir}

Unsur pertama yaitu claim, claim dapat diartikan sebagai gagasan pembicaraan. Claim pada artikel ini yaitu "Kehidupan normal baru yang menjaga keseimbangan antara kepentingan kesehatan dan kepentingan ekonomi ditempuh, dengan membuka kembali kegiatan ekonomi nasional secara bertahap, dan pada saat yang bersamaan tetap menerapkan protokol kesehatan dengan disiplin tinggi." Pengarang membangun gagasan terkait kehidupan normal baru sebagai sikap yang perlu diambil dalam menghadapi situasi pandemi Covid-19 ini. Bagaimana kebijakan yang diambil pemerintah dalam penanganan Covid-19 terkait kehidupan normal baru akan dipengaruhi oleh masukan informasi ilmiah di bidang epidemilogi serta pertimbangan sosial ekonomi dan politik. Tentu kebijakan ini membutuhkan kompromi dari para pemangku kepentingan di bidang kesehatan, sosial, ekonomi, dan politik. Beberapa langkah penyesuaian kebijakan juga diambil, mengikuti perkembangan situasi, kepentingan, informasi, dan angka kasus Covid-19 di lapangan yang dinamis dan terus menaik secara eksponensial. Claim akan kuat kedudukannya apabila terdapat data yang berkaitan dengan claim. Adapun data yang mendukung claim yakni "Tatanan normal baru diterapkan oleh pemerintah awal Juni, saat kurva penambahan kasus baru Covid-19 belum menunjukkan tanda-tanda menurun.". Pernyataan ini merupakan data. Terkait kebijakan pemerintah yang membuka kembali kegiatan ekonomi dengan menyimulasikan pelonggaran pembatasan sosial berskala besar (PSBB), dengan mulai membuka kembali akses transportasi, mal, dan pasar, dan disusul sektor lain secara bertahap. Data berikutnya yaitu "Selama Juni, jumlah kasus Covid-19 naik dua kali lipat dari 28.000-an menjadi 57.000-an.". Pernyataan ini merupakan data. Bahwa pelonggaran PSBB untuk menuju kehidupan normal baru akan tetapi kasus Covid-19 naik dua kali lipat. Artinya, penegakan disiplin dengan kepatuhan tinggi terhadap protokol kesehatan belum berjalan maksimal. Unsur selanjutnya adalah warrant. Warrant dalam artikel ini yaitu "Perlunya pemantauan berkelanjutan dalam penerapan normal baru sebagai upaya menjaga kestabilan kondisi negara.". Pernyataan tersebut menghubungkan claim dengan data yang ada di artikel ini. Unsur selanjutnya yaitu backing. Di dalam artikel ini tidak ditemukan backing. Unsur selanjutnya yaitu qualifer. Qualifer dalam artikel ini terdapat kata penanda "dan pada saat" pada pernyataan di claim. Unsur argumentasi yang terakhir yaitu rebuttal. Kendati demikian dalam artikel ini tidak ditemukan atau tidak memiliki unsur rebuttal terhadap claim.

\section{Apa Setelah Demam Babi Afrika, Covid-19, dan Flu Babi?}

Unsur pertama yaitu claim, Claim pada artikel opini ini yaitu "China bagaikan sudah jatuh ditimpa tangga pula.". Claim tersebut yang mendasari pada pembicaraan dalam artikel ini. Pengarang menuliskan permasalahan atau wabah-wabah yang dialami oleh negara China. Wabah pertama yaitu demam babi Afrika, penyakit yang tidak menular ke manusia ini menyebabkan kematian babi dalam jumlah yang tidak wajar. Wabah kedua yaitu Covid-19, yang saat ini tengah menjadi wabah dunia dan masih dalam tahap penanggulangan hampir 
disetiap negara. Wabah ketiga yaitu flu babi, virus yang penyebabnya berasal dari babi dan menyebar antar orang yang menyebabkan kematian. Claim tersebut tidak berdiri sendiri. Claim akan kuat kedudukannya apabila terdapat data-data yang berkaitan dengan claim. Adapun data yang mendukung claim yakni "Agustus 2018, untuk pertama kali China tertular penyakit paling ganas pada babi, demam babi Afrika. Diperkirakan 25 persen dari ratusan juta populasi babi mati pada April 2020. Pada bulan Desember 2019 muncul wabah Covid-19, kemudian menjadi pandemi. Kemudian baru-baru ini peneliti di China menemukan virus flu babi baru (G4 EA H1N1) yang menulari 10 persen peternak, dan disebut berpotensi menjadi pandemi (Proceedings of the National Academy of Sciences).". Pernyataan ini merupakan data. Demam babi Afrika yang menyebabkan kematian babi dengan jumlah yang tidak wajar, ditambah lalu lintas impor-ekspor babi menjadikan penyebaran virus ini tidak hanya terjadi di China. Perlu pemantauan dan penulusuran lebih lanjut dalam penanggulangannya. Demikian pula dengan wabah Covid-19 yang saat ini tengah menjadi wabah dunia yang menciptakan kebiasaan baru dan masih dalam tahap penanggulangan di beberapa negara. Flu babi juga menjadi wabah yang baru muncul di China, flu babi yang menyebar antar orang ini tetap perlu diwaspadai karena dapat berpotensi menjadi pemicu pandemi. Unsur selanjutnya adalah warrant. Warrant dalam artikel ini yaitu "Permasalahan di China perlu diwaspadai tetapi tidak ikut panik.". Pernyataan tersebut menghubungkan claim dengan data yang ada di artikel ini. Unsur selanjutnya yaitu backing. Di dalam artikel ini tidak ditemukannya backing. Unsur selanjutnya yaitu qualifer. Qualifer dalam artikel ini terdapat kata penanda "sudah" pada pernyataan di claim. Unsur argumentasi yang terakhir yaitu rebuttal. Kendati demikian dalam artikel ini tidak ditemukan atau tidak memiliki unsur rebuttal terhadap claim.

\section{Covid-19 dan Kesehatan Masyarakat}

Unsur pertama yaitu claim, Claim pada artikel opini ini yaitu "Kita harus tetap fokus untuk terus membangun kejayaan Indonesia sebagai bangsa yang kuat dengan mengutamakan kesehatan setiap warga negaranya.". Claim tersebut yang mendasari pada pembicaraan dalam artikel ini. Pengarang membangun gagasan terkait kesehatan masyarakat yang menjadi amanah pemerintah dan implementasinya bagi para warganya terlebih saat kondisi pandemi Covid-19 seperti ini. Tindakan-tindakan dalam membangun kejayaan terutama bidang kesehatan bagi rakyatnya, tentu tindakan ini bukan hanya yang bersifat penyembuhan tetapi juga pencegahan. Kedua hal ini dapat berjalan bersamaan. Claim akan kuat kedudukannya apabila terdapat data yang berkaitan dengan claim. Adapun data yang mendukung claim yakni "Jaminan Kesehatan Nasional (JKN) adalah salah satu program single-payer terbesar dan paling ambisius di dunia. Diluncurkan pada Januari 2014, JKN telah mencakup 221 juta orang, atau 83 persen dari populasi Indonesia pada Mei 2020.”. Pernyataan ini merupakan data. Bagaimana pemerintah berkomitmen untuk memastikan keberlanjutan JKN dan memiliki dampak positif pada hasil kesehatan, perlindungan keuangan, ekuitas kesehatan, dan pada pasar kesehatan, dan ekonomi secara umum. Akan tetapi defisit tahunan terus meningkat sehingga menambah tekanan pada sistem perawatan kesehatan Indonesia. Data berikutnya yaitu "Sistem JKN yang kita miliki merupakan pendekatan kuratif. Porsi yang dialokasikan untuk program-program preventif dengan peningkatan kesehatan masyarakat, pencegahan, dan pengendalian penyakit serta pendidikan hanya sekitar 7 persen dari keseluruhan alokasi anggaran kesehatan 2021.”. Saat slogan mencegah lebih baik daripada mengobati, namun kegiatan-kegiatan yang dibangun pada sistem JKN lebih condong pada hal yang bersifat penyembuhan. Dengan demikian diperlukan program-program yang dapat lebih mengedukasi untuk suatu pencegahan, terlebih saat pandemi Covid-19 seperti ini. Selanjutnya adalah warrant. Warrant dalam artikel ini yaitu "Usaha kuratif yang berorientasi jangka pendek dan menengah, serta preventif yang berorientasi jangka panjang, harus berjalan beriringan.". Pernyataan tersebut menghubungkan claim dengan data yang ada di artikel ini. Unsur selanjutnya yaitu backing. Di dalam artikel ini ditemukan backing yaitu "Salah satu contoh fokus program peningkatan kesehatan masyarakat adalah peningkatan kesehatan ibu dan anak. Ikatan Bidan Indonesia (IBI) mencatat, pandemi ini mengakibatkan wanita hamil dan pasangan enggan untuk mengunjungi fasilitas kesehatan, 
bahkan hanya menjalani pemeriksaan atau menerima kontrasepsi.". Dengan adanya bukti tersebut menjadi contoh kegiatan atau program yang berusaha untuk preventif dengan meningkatkan kesehatan ibu dan anak. IBI sebagai organisasi profesi yang memiliki anggota yang cukup besar yang anggotanya bekerja pada semua fasilitas pelayanan kesehatan baik di rumah sakit dan Puskesmas, berperan penting dalam memastikan bahwa ibu dan anak mendapatkan pelayanan kebidanan yang aman, efektif, dan yang terbaik. Dengan begitu backing di atas adalah fakta yang mampu mendukung warrant. Unsur selanjutnya yaitu qualifer. Qualifer dalam artikel ini terdapat kata penanda "setiap" pada pernyataan di claim. Unsur argumentasi yang terakhir yaitu rebuttal. Kendati demikian dalam artikel ini tidak ditemukan atau tidak memiliki unsur rebuttal terhadap claim.

\section{Covid-19 dan Pembangunan}

Unsur pertama yaitu claim. Claim pada artikel ini adalah "Covid-19 masa akhirnya belum diketahui. Vaksin yang mujarab belum diketahui. Karena itu perlu dipelihara suasana dan iklim politik yang sejuk dan bertanggung jawab. Sangat penting menggunakan dana keuangan negara yang terbatas untuk menyelamatkan pendidikan angkatan bonus demografi.". Claim tersebut yang mendasari pada pembicaraan dalam artikel ini. Pengarang membangun gagasan terkait permasalahan pandemi Covid-19 dan sikap Indonesia dalam menghadapi bonus demografi ini. Hal ini bertujuan untuk menjaga pembangunan negara agar tidak mengalami kemunduran atau ketertinggalan atas pandemi Covid-19 ini. Dengan demikian dibutuhkan proses yang adaptif dalam menyelamatkan generasi yang ada. Sebagaimana dunia memandang Indonesia sebagai negara kaya dan beraneka ragam sumber daya alam hayati daratan dan lautan yang terbentang sepanjang khatulistiwa. Namun rendahnya kualitas sumber daya manusianya (SDM) menjadikan lambannya tingkat pembangunan dan rendahnya pendapatan per penduduknya. Fokus dalam peningkatan kualiatas sumber daya manusia adalah penting di tengah pandemi Covid-19 agar tidak semakin tertinggal dari negara-negara maju lainnya. Claim akan kuat kedudukannya apabila terdapat data yang berkaitan dengan claim. Adapun data yang mendukung claim yakni "Indonesia mulai memasuki tahap bonus demografi dengan dominasi kelompok penduduk usia 15-64 tahun yang jumlahnya naik dari 170,79 juta (2015) ke 193,71 juta jiwa (2045).". Pernyataan ini merupakan data. Sebagaimana sejarah bangsa ini menunjukkan bahwa umumnya Indonesia dipimpin oleh pemimpin yang mencapai puncak produktivitasnya pada usia 40-50 tahun. Dengan demikian calon-calon pemimpin pontensial bangsa ini dan para pengelola pembangunan pada saat Indonesia lepas landas 2045 ada pada mereka yang kini berada pada kelompok usia 15-35 tahun. Oleh karenanya penting memperioritaskan pembangunan pada pengembangan kualitas SDM kelompok usia bonus demografi saat ini. Data berikutnya adalah "Hingga awal Juli, dilaporkan terdapat 402 kabupaten/kota berisiko "tinggi-sedang-rendah" dan 112 kabupaten/kota tidak ada risiko tinggi. Dengan demikian, sekitar 20 persen dari jumlah kabupaten/kota bisa diterapkan pengajaran tatap muka, sedang sisanya perlu "pengajaran berjarak" melalui teknologi digital.". Pernyataan ini merupakan data. Bahwa di 402 kabupaten/kota ini perlu dibangun fasilitas komunikasi digital, listrik, dan juga peningkatan kemampuan pendidikan dalam menguasai teknik pengajaran digital. Hal ini akan berguna dalam menjaga dan meningkatkan kualitas SDM angkatan bonus demografi dengan tetap menjalankan dunia pendidikan di tengah wabah Covid-19. Selanjutnya adalah warrant. Warrant dalam artikel ini yaitu "Perhatian pada kualitas sumber daya manusia di tengah masa pandemi Covid-19 menjadi acuan dalam wajah negara dimasa depan terlebih keberhasilan pemanfaatan bonus demografi pada Indonesia.". Pernyataan tersebut menghubungkan claim dengan data yang ada di artikel ini. Unsur selanjutnya yaitu backing. Di dalam artikel ini ditemukan backing yaitu "Kalau kesempatan meningkatkan kualitas generasi muda yang bakal menjadi soko guru dan pimpinan masyarakat untuk mewujudkan mimpi Indonesia lepas landas 2045 tidak terwujudkan, Republik Indonesia akan terperosok ke dalam jurang "negara gagal" yang sulit bangkit di masa depan.". Backing tersebut adalah fakta. Dengan adanya bukti tersebut menjadi jelas bahwa bangsa ini perlu belajar dari pengalaman-pengalaman negara lain. Agar dapat memadukannya pada proses peninggkatan 
negara dalam menyukseskan pemanfaatan bonus demografi ini. Adapaun berbagai latar belakang dan profesi dapat turut membantu peluang pemanfaatan bonus demografi ini. Dengan begitu backing di atas adalah fakta yang mampu mendukung warrant. Dengan tetap memperhatikan sumber daya manusia di tengah situasi Covid-19 seperti ini. Unsur selanjutnya yaitu qualifer. Qualifer dalam artikel ini terdapat kata penanda "karena itu" pada pernyataan di claim. Unsur argumentasi yang terakhir yaitu rebuttal. Kendati demikian dalam artikel ini tidak ditemukan atau tidak memiliki unsur rebuttal terhadap claim.

\section{Otopsi Jenazah Korban Covid-19}

Unsur pertama yaitu claim, claim dapat diartikan sebagai gagasan pembicaraan. Claim pada artikel opini ini adalah "Dengan otopsi, dokter dan coass bisa melihat dengan mata sendiri (seeing is believing) organ paru jenazah Covid-19 yang dikepung oleh sel megakariosit sehingga terjadi penggumpalan masif. Semua itu memberikan konfirmasi langsung dengan impresi kuat, pasien korona mengalami sesak napas hebat hingga akhirnya gagal bernapas.". Claim tersebut yang mendasari pada pembicaraan dalam artikel ini. Pengarang menuliskan tentang manfaat otopsi serta peranannya terlebih dimasa pandemi Covid-19 seperti ini. Sebagai salah satu langkah yang diambil dari bagian prosedur medis untuk mengetahui atau menginvestigasi virus Covid-19 ini. Hal ini bersamaan dengan pendapat para patolog yang mengatakan bahwa penyelidikan penyebab kematian yang digali dari otopsi lebih tinggi 10-30 persen dibandingkan tanpa otopsi. Claim tersebut tidak berdiri sendiri. Claim akan kuat kedudukannya apabila terdapat data-data yang berkaitan dengan claim. Adapun data yang mendukung claim yakni "Ahli patologi Amy Rapkiewicz memimpin tim otopsi New York University Langone Health. Adapun hasil temuan yaitu beberapa organ penting seperti paruparu dipenuhi megakariosit yang melimpah, pemicu produksi zat pembeku. Akibatnya, darah jadi menggumpal, pengiriman oksigen tersendat, saluran pernapasan jadi tersumbat, dan pada tahap yang fatal pasien gagal bernapas. Inilah yang membantu menjelaskan mengapa pasien Covid-19 kesulitan bernapas. Temuan Amy dikuatkan Richard Vander Heide, dalam laporan yang dipublikasikan 10 April di New Orleans. Richard mengotopsi jenazah pasien berusia 44 tahun di LSU Health. Saat memotong paru, ditemukan ribuan mikroklot (gumpalan darah sangat kecil) yang berkontribusi pada penyakit parah dan dekompensasi atau payah jantung pada pasien Covid-19. Ini keadaan patologis utama, suatu hal yang tak biasa. ”. Pernyataan ini merupakan data. Temuan ini membuat dan memengaruhi kalangan dokter untuk memberikan obat pengencer darah pada pasien Covid-19. Dan studi ini membawa pandangan baru dalam konteks patofisiologi Covid-19. Serta memberi manfaat praktisnya yakni menawarkan justifikasi untuk rencana perawatan/pengobatan baru, termasuk strategi antikoagulasi yang diberlakukan oleh para klinisi. Selanjutnya adalah warrant. Warrant dalam artikel ini yaitu "Pada Covid-19 ini, otopsi kembali menunjukkan peran pentingnya, terlebih telah menghasilkan beberapa temuan penting yang sangat membantu pemetaan keganasan karakter virus super baru bernama lain SARS CoV-2 ini.". Pernyataan tersebut menghubungkan claim dengan data yang ada di artikel ini. Unsur selanjutnya yaitu backing. Di dalam artikel ini tidak ditemukannya backing. Unsur selanjutnya yaitu qualifer. Qualifer dalam artikel ini terdapat kata penanda "semua itu" pada pernyataan di claim. Unsur argumentasi yang terakhir yaitu rebuttal. Kendati demikian dalam artikel ini tidak ditemukan atau tidak memiliki unsur rebuttal terhadap claim.

\section{Bebas dari Cacar dan Covid-19}

Unsur pertama yaitu claim. Claim pada artikel opini ini adalah "Pelajaran dari keberhasilan bebas dari cacar telah digunakan untuk menanggapi wabah Covid-19. Seperti pengawasan, penemuan kasus, pemeriksaan, pelacakan kontak, karantina, dan kampanye komunikasi untuk menghilangkan informasi yang salah penting untuk kendalikan Covid-19.”. Pengarang membangun gagasan terkait pengalaman dunia ini dalam menghadapi wabah cacar hingga terbebas dari wabah tersebut, dan juga pengalaman lainnya yang sangat penting untuk dilihat kembali sebagai rujukan dalam pengambilan sikap saat menangani wabah Covid-19. Sebagaimana dunia berhasil menyingkirkan cacar berkat solidaritas global yang luar biasa dan 
Jurnal SEMANTIKA, Volume 2, No. 02, Februari 2021, pp. 16-27

adanya vaksin yang aman efektif, menjadikan kemenangan umat manusia atas cacar. Claim akan kuat kedudukannya apabila terdapat data-data yang berkaitan dengan claim. Adapun data yang mendukung claim yakni "Pada 8 Mei 1980, Majelis Kesehatan Dunia ke-33 resmi menyatakan, "Dunia dan seluruh rakyatnya telah bebas dari penyakit cacar." Deklarasi ini menandai berakhirnya satu penyakit infeksi yang telah merongrong manusia selama setidaknya 3.000 tahun, menewaskan 300 juta orang pada abad ke-20 saja.". Pernyataan ini merupakan data. Bahwa bebas dari cacar terjadi berkat upaya global selama 10 tahun yang dipelopori Organisasi Kesehatan Dunia (WHO) dengan melibatkan ribuan petugas kesehatan di seluruh dunia saat memberikan setengah miliar dosis vaksin untuk membasmi cacar. Atas kesolidaritasan warga global secara bersama dan kuat, umat manusia berhasil melewati wabah cacar. Data berikutnya yaitu "29 Juni 2020, WHO menentukan calon vaksin Covid-19 yang dikembangkan sejumlah negara: 17 calon vaksin potensial telah memasuki uji klinis, 132 calon lain dalam evaluasi praklinis.". Pernyataan ini merupakan data. Bahwa vaksin yang berfungsi untuk menghasilkan kekebalan tubuh terhadap suatu penyakit adalah sebagai jalan ikhtiar dalam dunia medis untuk menanggulangi wabah Covid-19 ini. Data berikutnya adalah "Di antara calon yang sudah memasuki uji klinis adalah inactivated SARS-CoV-2 yang dikembangkan Sinovac Biotech Ltd. Vaksin ini sudah sampai di Bandung untuk uji klinis tahap tiga setelah Prof Dr dr Kusnandi Rusmil SpA(K) MM, selaku Ketua Komite Etik Penelitian Universitas Padjajaran, memberikan persetujuan 27 Juli 2020.”. Pernyataan ini merupakan data. Bahwa negara dalam hal ini juga tengah berupaya semaksimal mungkin untuk bisa segera menanggulangi virus yang sedang mewabah baik di Indonesia juga di seluruh dunia. Sebagaimana keberhasilan dunia saat menanggulangi wabah cacar, dalam hal ini Indonesia telah turut mempraktikkannya dengan bekerja sama bersama negara-negara luar. Karena jika bicara penanggulangan wabah Covid-19 sejatinya adalah tentang rasa kemanusiaan, yang semua orang berhak untuk terbebas dari wabah ini. Terpenting dibutuhkan kesolidaritasan yang absolut. Selanjutnya adalah warrant. Warrant dalam artikel ini yaitu "Momentum sertifikasi bebas dari cacar (freedom from smallpox) mengingatkan kita akan pentingnya solidaritas lintas sektor secara global plus ilmu pengetahuan dalam wujud vaksin, yang akan menghasilkan solusi.". Pernyataan tersebut menghubungkan claim dengan data yang ada di artikel ini. Unsur selanjutnya yaitu backing. Di dalam artikel ini ditemukan backing yaitu "Dirjen WHO Tedros Adhanom Ghebreyesus mengatakan, "Ketika dunia menghadapi pandemi Covid-19, kemenangan umat manusia atas cacar adalah pengingat akan apa yang mungkin dilakukan ketika semua negara bersatu melawan ancaman masalah kesehatan bersama." Dunia berhasil menyingkirkan cacar berkat solidaritas global yang luar biasa dan adanya vaksin yang aman dan efektif.". Backing di atas adalah fakta. Dengan adanya bukti tersebut menjadi jelas bahwa semangat pengalaman dan sejarah itu harus terpupuk dengan tetap optimis dalam menanggulangi wabah Covid-19 ini. Hingga berita baik nantinya juga sama kita dengar akan WHO mempublikasikan bebasnya peradaban manusia dari wabah Covid-19. Dengan begitu backing di atas adalah fakta yang mampu mendukung warrant. Unsur selanjutnya yaitu qualifer. Qualifer dalam artikel ini terdapat kata penanda "seperti" pada pernyataan di claim. Unsur argumentasi yang terakhir yaitu rebuttal. Rebuttal adalah hampir sama dengan qualifer, bagian yang memungkinkan untuk mengecualikan tanpa harus menganggap claim sebagai sesuatu yang benar secara umum. Kendati demikian dalam artikel ini tidak ditemukan atau tidak memiliki unsur rebuttal terhadap claim.

\section{Covid-19 dan Aspek Historikal Struktural BUMN}

Unsur pertama yaitu claim, claim dapat diartikan sebagai gagasan pembicaraan. Claim pada artikel opini ini adalah: "Maka, usaha Presiden Jokowi menciptakan "duet" Airlangga-Erick Thohir dengan Budi Sadikin bertindak sebagai asisten, telah sekaligus menggambarkan sebuah kondisi baru: BUMN-led Economy.". Claim tersebut yang mendasari pada pembicaraan dalam artikel ini. Pengarang menuliskan tentang kebijakan pemerintah dalam bidang ekonomi di tengah kondisi pandemi Covid-19. Bagaimana penanganan Covid-19 dan pemulihan ekonomi nasional dibentuk oleh pemerintah sebagai jalan strategi untuk menanggulangi krisis ekonomi 
yang terjadi. Bahwa aksi yang dilakukan Presiden Jokowi ini secara teoritis membuka momentum baru bagi transformasi peranan BUMN yang jauh lebih berarti. Claim akan kuat kedudukannya apabila terdapat data-data yang berkaitan dengan claim. Adapun data yang mendukung claim yakni "Pertama, "duet" Airlangga-Erick Thohir memberikan gambaran bagaimana negara bertindak dalam situasi krisis tak berpreseden. Kemudian hal ini memperlihatkan "perombakan" struktur dan hierarki kewenangan ekonomi dari yang konvensional berlaku. Kedua, krisis ekonomi akibat Covid-19 ini telah melumpuhkan perekonomian.". Bahwa banyak kaum pekerja telah dirumahkan baru-baru ini, kemudian ditambah dengan pengangguran yang telah berlangsung sebelumnya, keadaan ini melumpuhkan ekonomi. Dengan demikian dana tertumpuk di dunia perbankan tanpa penyaluran produktif, tindakan merumahkan kaum pekerja tersebut menahan aksi belanja perorangan, rumah tangga, serta korporasi (besar dan kecil). Selanjutnya adalah warrant. Warrant dalam artikel ini yaitu "Pandemi Covid-19, yang juga tak berpreseden itu, memaksa restukturisasi kewenangan dan ketegasan dalam strategi kebijakan yang dibuat.”. Pernyataan tersebut menghubungkan claim dengan data yang ada di artikel ini. Unsur selanjutnya yaitu backing. Di dalam artikel ini ditemukannya backing yaitu "Dalam konteks inilah, BUMN sebagai kekayaan produktif negara yang telah terkonsolidasikan menjadi tumpuan. Seruan Menteri Koordinator Kemaritiman Luhut B Pandjaitan kepada direksi BUMN mengintensifkan penggunaan komponen dalam negeri (TKDN). Bahwa dalam "kelesuan" ekonomi, BUMN harus tampil sebagai "benteng" negara dalam penyelamatan perekonomian nasional.". Dengan adanya bukti tersebut menjadi jelas bahwa di tengah kondisi pandemi Covid-19 ini menjadi hal yang sangat dibutuhkan untuk bahan belanja negara menggunakan produk-produk dalam negri. Agar mempercepat laju pertumbuhan ekonomi di dalam negri dan segera tercipta keseimbangan dalam menanggulangi krisis kesehatan dan krisis ekonomi. Dengan begitu backing di atas adalah fakta yang mampu mendukung warrant. Unsur selanjutnya yaitu qualifer. Qualifer dalam artikel ini terdapat kata penanda "maka" pada pernyataan di claim. Unsur argumentasi yang terakhir yaitu rebuttal. Kendati demikian dalam artikel ini tidak ditemukan atau tidak memiliki unsur rebuttal terhadap claim.

\section{Meluruskan Infodemi Covid-19}

Unsur pertama yaitu claim, claim pada artikel opini yang berjudul Meluruskan Infodemi Covid19 adalah "Informasi yang membingungkan masyarakat (dinamakan infodemi) kian membanjir pada era pandemi Covid-19. Menjadikan orang kian bingung dan tak mengambil langkahlangkah efektif mengendalikan wabah, tetapi justru menghabiskan biaya buat pilihan yang tak ada gunanya, bahkan mungkin membahayakan.". Pengarang menuliskan tentang konsumsi informasi yang diterima masyarakat banyak yang membingungkan terlebih informasi tentang Covid-19. Di tengah era percepatan dengan segala informasi juga bergerak dengan sangat cepat dan terkadang tak ada filter di dalam sana. Membuat manusia harus memiliki tameng tersendiri dalam mengkonsumi informasi-informasi yang beredar. Sebagaimana di tengah bencana atau wabah penyakit yang kita alami sekarang, biasanya ada dua situasi yang sering muncul, pertama adalah ketidakberdayaan, dan kedua adalah tawaran solusi masalah bencana berupa tokoh, barang, atau prosedur tertentu, yang belum pasti kebenarannya. Claim akan kuat kedudukannya apabila terdapat data yang berkaitan dengan claim. Adapun data yang mendukung claim yakni "Analisis interaksi Facebook pada 100 juta orang dengan pelbagai pandangan berbeda tentang vaksinasi. Uji klinis vaksin masih berlangsung, tetapi sudah dipetakan bahwa 4,2 juta orang yang antivaksin lebih terkoneksi dengan mereka (74,1 juta orang) yang masih belum memutuskan setuju atau tak setuju vaksinasi ketimbang 6,9 juta orang yang mendukung penggunaan vaksin untuk mencegah Covid-19.". Masyarakat dibingungkan oleh tawarantawaran solusi mengatasi pandemi saat ini. Dan infodemi dengan tingkat yang tinggi hanya akan memperkeruh upaya penanggulangan wabah global. Penting bagi WHO dengan bekerjasama oleh banyak media platform saat ini guna menyaring informasi yang menyesatkan dan menampilkan informasi yang terpercaya. Selanjutnya adalah warrant. Warrant dalam artikel ini yaitu "Infodemi bukan hanya persoalan di Indonesia tetapi juga masalah global, dengan 
Jurnal SEMANTIKA, Volume 2, No. 02, Februari 2021, pp. 16-27

ketidakpercayaan terhadap ilmu dan ilmuwan, lebih mengandalkan media sosial, respons tokoh-tokoh negara membingungkan, yang kemudian banyak memunculkan persepsi lain.". Pernyataan tersebut menghubungkan claim dengan data yang ada di artikel ini. Unsur selanjutnya yaitu backing. Di dalam artikel ini ditemukannya backing yaitu "Presiden $A S$ Donald Trump pernah menganjurkan penelitian apakah menyuntikkan diisnfektan dapat mencegah Covid-19, yang mendapat reaksi keras dari para dokter. Tak kalah membahayakan anjuran Presiden Brasil Jail Bolsonaro untuk mencegah Covid-19 dengan obat malaria chloroquine tanpa pengawasan dokter. Infodemi tingkat tinggi memperkeruh upaya penanggulangan wabah global ketika Trump menuduh WHO antek China karena lambat mengumumkan pandemi Covid-19. '. Backing di atas adalah fakta. Dengan adanya bukti tersebut menjadi jelas bahwa dimasa pandemi Covid-19 ini sangat riskan seseorang dalam mengeluarkan pandangannya, terlebih jika orang tersebut adalah tokoh atau figur yang juga berpengaruh. Hal ini akan membendung infodemi di masyarakat, dan kegamangan akan sumber informasi yang harus dirujuk. Penting untuk menjaga situasi yang kondusif disamping mencari solusi untuk menghadapi wabah Covid-19 ini. Meminimalisir infodemi agar masyarakat tidak dirugikan atau tidak mengambil langkah-langkah yang sebenarnya membahayakan. Mengembalikan kepercayaan kepada para ahli ilmu kesehatan dengan tidak terlalu mengandalkan dunia sosial media. Dengan begitu backing di atas adalah fakta yang mampu mendukung warrant. Unsur selanjutnya yaitu qualifer. Qualifer dalam artikel ini terdapat kata penanda "mungkin" pada pernyataan di claim. Unsur argumentasi yang terakhir yaitu rebuttal. Dalam artikel ini tidak ditemukan atau tidak memiliki unsur rebuttal terhadap claim.

\section{SIMPULAN}

Kolom Opini dalam koran Kompas yang terkumpul dalam rentang waktu 1 bulan secara daring, sebanyak 10 artikel menjadi objek dalam penelitian ini. Dengan hasil kesepuluh artikel telah memenuhi elemen utama unsur-unsur argumentasi yaitu claim, data, dan warrant. Namun kesepuluh artikel tidak mendekati kesempurnaan unsur dengan memenuhi elemen pelengkap unsur-unsur argumentasi yaitu backing, qualifer, dan rebuttal. Bahwa dari kesepuluh artikel, tiga artikel hanya memiliki satu elemen pendukung dan tujuh artikel hanya memiliki dua elemen pendukung.

\section{REFERENCES}

[1] J. B. Freeman, "Argument structure: Representation and theory," in Argumentation Library, 2011.

[2] D. Zarefsky, "Argumentation, the Study of Effective Reasoning," in Argumentation, the Study of Effective Reasoning, 2005.

[3] Y. Setyaningsih, "Pola Argumen Paragraf Argumentatif Pada Artikel Jurnal Terakreditasi Bidang Ekonomi (Perspektif Stephen Toulmin)," Adab. J. Bhs. dan Sastra, vol. 15, no. 2, p. 136, 2016, doi: 10.14421/ajbs.2016.15202.

[4] T. Govier, Problems in Argument Analysis and Evaluation. 2018.

[5] R. Puspita, "Mediamorfosis Surat Kabar Ke Surat Kabar Online," J. Komunikasi, Masy. dan Keamanan, vol. 1, no. 1, pp. 11-28, 2019.

[6] D. Praditya, "Digitalisasi dan Konvergensi Media," J. Obs., vol. 10, no. 2, 2012.

[7] A. Susilo et al., "Coronavirus Disease 2019: Tinjauan Literatur Terkini," J. Penyakit Dalam Indones., vol. 7, no. 1, p. 45, 2020, doi: 10.7454/jpdi.v7i1.415.

[8] T. P. R. N. Hapsari and A. S. Fitria, "Efektivitas Pembelajaran Daring Mata Kuliah Evaluasi Pengajaran Bahasa Dan Sastra Indonesia Masa Pandemi Covid-19," J. Ilm. Semant., vol. 2, no. 01, pp. 11-20, 2020, doi: 10.46772/semantika.v2i01.259.

[9] P. Y. Kurniawan, A. Ariska, A. N. Fauzi, and E. R. Nuraeni, "Analisis Tanda Dan Lambang Pada Banner Pencegahan Penularan Covid-19," J. Ilm. Semant., vol. 2, no. 01, pp. 62-68, 2020, doi: 10.46772/semantika.v2i01.265. 